\title{
Team Learning and Its Impact on Marketing Team Performance: An Empirical Study
}

\author{
Masoodul HASSAN (Corresponding author) \\ Department of Management Sciences, Mohammad Ali Jinnah University \\ Islamabad, Expressway, Kahuta Road, Zone-V, Islamabad \\ E-mail: masoodulhassan99@yahoo.com
}

Ibrahim AKSEL

Faculty of Economics and Administrative Sciences,

Department of Business Management and Organization, Pamukkale University

Kinikli Kampusu, 20070, Denizli-TURKEY

E-mail: iaksel@pamukkale.edu.tr

Muhammad Zafar YAQUB

Center for Business Studies, University of Vienna, Brünner Straße 72, 1210 Vienna, Austria

E-mail:mzyaqub7@yahoo.co.uk

\section{Zelal ALDEMIR}

Universitat Autonomous de Bercelona, Department d'Economia de l'Empesa, Campus UAB, Edifici

E-mail: zelal.aldemir@superonline.com

Received: June 26, 2011

Accepted: July 12, 2011

doi:10.5539/ibr.v4n4p124

An earlier version of this paper was presented at the Ankara University International Conferene Marketing And Entrepreneurship AUMEC Antalia on Aprll, 2009

\begin{abstract}
The paper explains the effects of internal and external team learning behaviors on the performance of marketing teams. The survey was conducted in the context of a multinational Pharmaceutical Corporation marketing its products in Turkey. Data were collected from members of marketing team which included medical sales representatives, specialized medical sales representatives and districts heads of marketing. The results indicate that both the internal team learning and the external team learning behaviors play significant roles in ensuring the success of marketing teams in continuously identifying, anticipating and satisfying the customer requirements profitably through an efficient deployment of the marketing teams' resources.
\end{abstract}

Keywords: Team learning, team performance, organizational learning, Individual learning

\section{Introduction}

Gryskiewicz (1999) argues that to develop a favorable climate for creativity, innovation and renewal, the organizations need to develop teams which work on a shared philosophy, are interdependent and are keen to learn on how to enhance their performance by working together. The relationship between team performance and the collective intelligence of a team has a larger value compared to the sum of intelligence of individual members (Senge 1992). Therefore, the leaning-performance phenomenon, which adequately demonstrates synergy (Christopher, Pearson and Entrekin 2003), fosters higher levels of adaptability, productivity and creativity than any individual employee can offer, and eventually results in sophisticated, innovative and comprehensive solutions to the organizational problems (Beers 2005; Savelsbergh, Heijden. and Poell 2007).

Savelsbergh et al. (2007) have summarized the influence of a host of variables on team performance. These variables include diversity of team members (Schippers, Den Hartog, Koopman, and Wienk 2003), task interdependence (Edmondson 1999; Edmondson, Dillon and Roloff 2007; Van der Vegt 1998); team context such as supportiveness of the leader (Arnold, Arad, Rhoades and Drasgow 2000; Shivrastava, Bartol and Locke 2006) and certain organizational characteristics (Anderson and West 1998). Most of the research findings show that 
relationships between predictor variables and team performance are complex and there still exists considerable lack of empirical knowledge on the predictive validity of the variables influencing team performance.

Christopher et al. (2003) used Edmondson's (1996) Team Learning Survey (TLS) and Team Performance Survey (TPS) for conducting their research in one Australian hospital to examine the effects of internal and external team learning on team performance. Using the same methodology, our study aims at investigating the effects of (internal \& external) team learning behaviors on team performance among the marketing team members working in a multinational pharmaceutical company located in Turkey.

\section{Literature review}

Mathieu, Rapp and Gilson (2008) regard team as collectives who exist to perform organizationally relevant tasks, share one or more common goals, interact socially, exhibit task interdependencies, maintain and manage boundaries, and are embedded in an organizational context that sets boundaries, constrains the team, and influences exchanges with other units in the broader entity. Hackman (1983) defines team as a social system that consists of at least two members who share responsibility for a team product or service, recognize themselves as a group and are recognized as such by others as well. Luthans (1995) refers Katzenback and Smith (1993) to differentiate between teams and traditional work groups by pointing out that teams go beyond traditional formal work groups by creating a collective output as well as synergistic effects. Teams can be formed for any purpose and may be categorized as advice teams, production teams, project teams, action teams (Sundstrom 1999), cross-functional teams, self managed teams (Luthans 1995) and/or virtual teams (Kraut and Korman 1999).

Learning can be defined as the process of acquiring knowledge through experience which leads to an enduring change in behavior (Buchanan and Huczynski 2004). Loewen and Loo ( 2004) in the context of importance of team learning quote words of Senge, Roberts, Ross, Smith and Kleiner (1994: p.354) as 'history has brought us to a moment where teams are recognized as a critical component of every enterprise - the predominant unit for decision making and getting things done'. Team learning is the essence of organizational learning and change (Senge 1992). Ancona and Chong (1999) have found that teams enhance the ability to survive, improve and adapt to the changing circumstances. Chang and Lee (2001) have revealed that an organization learns through acquiring, retaining and transferring knowledge. Moreover, Chang and Lee (2001) have also cited the findings of Kilgore (2001) on collective learning by asserting that certain learning behaviors originated from collective system and social interaction lead to the emergence of collective learning products such as shared ideas, beliefs, mental models, knowledge and action and help individuals to engage in integration process. As such, team learning can be regarded as a social phenomenon.

Christopher et al. (2003) found that the use of teams provides the merits of empowering people to utilize their abilities effectively which allows the managers to focus their attention on strategic priorities instead of just supervising the subordinates which eventually not only improves their efficiency (Entrekin and Court 2001) but also brings knowledge, skills and experience to the workplace (Avery 2000). These intellectual assets help in operating the organization effectively and efficiently (Brooks 1994) through creating synergies (Jassawalla and Sashittal 1999). The enhancement of team learning accumulated through the deployment of cross-functional teams helps in gaining greater competitive advantage (Banker, Field, Schroeder and Sinha 1996), enhancing continuous improvements of quality, innovation, customer satisfaction (Boyett and Conn 1991) as well as the employee satisfaction; reducing cost and improving adaptability to the technological change (Wellins, Byham and Wilson 1991).

Analyzing the aspects of individual and team learning has considerable potential to enhance understanding of the organizational learning (Hayes and Allinson 1998; Lundberg 1995). It has been profoundly recognized that organizations can learn better if teams in the organizations learn collectively through experience and knowledge sharing among individuals (Bain 1998; Bernnett, Kremer and O’Brien 1994; Berg 1993; Brwon and Duguid 1998). Savelsbergh et al. (2007) have referred (Argyris and Schön (1978), Gibson and Vermeulen (2003), Kasl, Marsick and Dechant (1997) and Van der Vegt and Bunderson (2005) to reflect a positive association of team performance with the team learning behaviors such as asking questions, challenging assumptions, evaluating alternatives, seeking feedback, experimenting, reflecting on results, detecting, discussing and correcting errors, and reflective communication. Although considerable research has been done on the learning in organizations yet relatively little is known about team learning (Edmondson 1999). Moreover, Edmondson (1999) has revealed that the empirical work on team learning is limited. The present study bridges this research gap in the literature.

\section{The Conceptual Model}

Mathieu et al. (2008) found that teams generate operational outcomes, financial outcomes, behavioral outcomes and/or attitudinal outcomes which may be used in order to investigate teams' effectiveness in organizations (Argote and McGrath 1993, Barrick, Bradley, Kristof-Brown and Colbert 2007; Goodman, Ravlin and Schminke 1987; Stewart 2006). Following Savelsbergh et al. (2007), we have taken into consideration the five types of team learning behaviors based upon Edmondson (1996) which include: 
1) Exploratory questioning and cumulative reasoning: sharing knowledge, opinions, perspectives and constructively managing differences in opinion (Van den Bossche, Gijselaers, Segers and Kirschner 2006);

2) Reflection: on experiences, goals, actions, working methods, strategies, adapting working methods, strategies or assumptions (Schippers et al. 2003);

3) Error management: by collectively discussing errors exploring how to prevent those (Van Dyck, Frese, Baer and Sonnentag 2005);

4) Feedback seeking behaviors: internally between team members and externally from outsiders upon the team; and to measure: Are we doing the right thing? Are we doing our things right: And drawing conclusions leading to further exploration or experimenting or adapting goals or assumptions (Schippers et al. 2003);

5) Experimenting: doing things differently than before and/or measuring differences in the outcome (Van Woerkom 2003).

Based upon these five team learning behaviors, Edmondson (1996) identified two learning behaviors constructs which include:

1) Internal team learning behaviors: defined as the extent to which team members engage in behaviors to monitor performance against goals, obtain new information, test assumptions, and create new possibilities 2) external team learning behaviors: defined as an assessment by several of the team's customers and/or managers about the extent to which team engages in behaviors such as seeking new information or asking those who receive or use its work for feedback (Argote and McGrath 1993).

Our baseline proposition is that by incorporating the above mentioned five learning behaviors together, the internal learning and the external learning impact team performance. Figure 1 depicts the same relationship.

\section{Methods}

\subsection{Data collection}

For data collection, we adapted the Team Learning Survey (TSL) and Team Performance Survey (TPS) scales used by Edmondson (1996) while investigating team learning in a large office furniture manufacturer in the American Mid-West. The Team Learning Survey (TLS) incorporated both the internal and the external team learning behaviors each measured through five items. The team performance construct in the Team Performance Survey (TPS) was also measured through five items. The respondents were asked to record their responses on a seven-point likert scale where 1 meant strongly disagree and 7 meant strongly agree. The questionnaire was translated in Turkish Language by the experts from Faculty of Business Administration, Istanbul University and sent to the respondents through mail.

\subsection{The case study site}

The questionnaires were sent to the members of marketing team of one multinational pharmaceutical company operating in Turkey. The marketing team of the company is composed of 90 members who have been distributed in 17 districts throughout the Turkey. By using the personal selling component of the promotions mix mostly, the members of the marketing team are responsible for achieving their respective targets and report to the concerned district marketing manager. The main reason behind the selection of this marketing firm for our research was its multinational base i.e. having a diversified team of marketing people where the team members every day learn about the needs of their customers and determine how to satisfy these needs through effective team performance. The survey involved all the 90 members of the marketing team. 49 out of 90 members returned the questionnaire yielding a response rate of $54 \%$.

\section{Results}

The results will be presented as follows: profile of the respondents, result findings of our three main constructs of our model, 1) Internal Team Learning, 2) External Team Learning 3) Team Performance in shape of factor analysis, correlations and regression analysis.

\subsection{Profile of the respondents}

$87 \%$ of the respondents were males and $13 \%$ were females. Most of the respondents i.e. $69 \%$ belonged to the $30-39$ years age group. Remaining $27 \%$ belonged to the $20-29$ years age groups and $4 \%$ were above 40 years of age. About $78 \%$ respondents were graduates, $18 \%$ had master degrees and $4 \%$ had doctorate degrees. $61 \%$ of the respondents were Sales representatives, $27 \%$ were specialized medical sales representatives and the rest (12\%) were districts managers. Finally, $75 \%$ of the respondents had the experience between $5-7$ years, $12 \%$ had the experience between $8-10$ years and $13 \%$ had the experience as 11 years or above.

\subsection{Factor Analysis and Descriptive Statistics}

With the help of SPSS, we performed the Principal Components Analysis (PCA) with Varimax rotation for the three 
latent constructs. In interpreting the items which load on each factor, Hill and Petty (1995) has referred Tinsley and Tinsley (1987) to state that 0.30 level is a generally accepted minimum factor loading because it indicates that approximately $10 \%$ of the variance for a corresponding variable has been explained by a factor. We used the same criterion. Internal Team Learning, External Team Learning and Team Performance accounted for 53.11\% of the common variance (see Table 1) and exhibited cronbach $\alpha$ as $0.74,0.64$ and 0.71 respectively, which according to Choo, Furness, Paquette, Van den Berg, Detlor, Bergeron and Heaton (2006) are above/closer to the minimum acceptable range of $0.65-0.70$ (DeVellis 1991).

Table 2 shows the mean scores of the three factors. The mean score of item 5 of internal team learning is 6.02 which reflect that the group members regularly take time to figure out ways to improve their work process. The mean score of item 1 of external team learning is 5.78 which reflect that group members go out and get all the relevant work information from customers and other parts of the organization. Similarly, the mean score of item 5 of team performance is 5.94 which reflect that the quality of work provided by the group is improving.

\subsection{Multivariate analysis}

The multivariate analyses were conducted using the aggregate scores. To get the aggregate scores, items scores pertaining to internal team learning, external team learning and team performance factors were summed. Table 3 shows the correlations among these variables. Team performance is significantly (positively) correlated with internal team learning and external team learning e.g. $40 \%$ and $38 \%$ respectively. Internal team learning is positively correlated with team performance and the external team learning e.g. $40 \%$ and $38 \%$ respectively. Similarly, external team learning is positively correlated with team performance and internal team learning factors e.g. $38 \%$ each. These positive correlations confirm our base-line hypothesis that a firm's internal team learning and external team learning impact organizational team performance. The extent of impact was gauged through the regression analyses.

\subsection{Regression analysis}

In order to study the extent of impact of internal team learning and the external team learning on team performance, regression analyses were carried out. The results are shown in tables 4-6. Table 4 shows the effect of internal team learning on team performance. The model's adjusted $\mathrm{R}^{2}$ is 0.142 and the $\mathrm{F}$ value for the model is significant at $\mathrm{p}<$ 0.01 . The standardized regression coefficient $(\beta=0.40)$ of internal team learning is significant at $p<0.05$. Table 5 shows the output of regression analysis of external team learning on team performance. The model's adjusted $\mathrm{R}^{2}$ is 0.125 and the $F$ value for the model is significant at $p<0.01$. The standardized regression coefficient $(\beta=0.379)$ of external team learning is significant at $\mathrm{p}<0.05$. Table 6 shows output of the regression analysis of both types of learning on the team performance. The model's adjusted $\mathrm{R}^{2}$ is 0.187 and the $\mathrm{F}$ value for the model is significant at $\mathrm{p}<0.01$. The standardized regression coefficients $(\beta)$ of internal team learning and the external team learning are 0.300 and 0.266 respectively with $\beta$ for the internal team learning being statistically significant at $\mathrm{p}<0.05$.

\section{Discussion and Conclusion}

We examined the effects of internal and external team learning on team performance in our case organization i.e. marketing unit of a multinational corporation based in Turkey. The results illustrated that both internal team learning and the external team learning have statistically significant impact on team performance which reflects that to improve the quality of work, members of the marketing team regularly take time to figure out and discuss ways internally and externally to improve work processes and learn from mistakes. Moreover, this means that the team learning behaviors play an important role in identifying, anticipating and satisfying the customer requirements profitably through an effective marshalling of the resources of marketing teams. It is worthwhile to take into account the limitations our research. We studied only one corporation, therefore, it is not clear to what extent the findings may be generalized to others organization. Another limitation is that the survey asked employees to report their observations of team learning behaviors; the reported observations may not be the same as the actual behaviors. In terms of contribution to theory, this study corroborates the work of Christopher et al. (2003) and Edmondson (1996). The future research should attempt to increase the explanatory power of the model by including the variables such as leadership empowerment, goal clarity, leader's mood, group potency and collective efficacy in addition to the (internal and external) team learning behaviors especially in context of the project teams and the virtual teams which are being widely used in the contemporary organizations.

\section{References}

Ancona, D.G., and Chong, C. (1999). Cycles and Synchrony: The Temporal Role of Context in Team Behavior, Research on Managing Groups and Teams, Volume 2, pp. 33-48.

Anderson, N. and West, M. (1998). Measuring Climate for Work Group Innovation: Development and Validation of the Team Climate Inventory, Journal of Organizational Behavior, volume 19, pp. 235-258, http://dx.doi.org/10.1002/(SICI)1099-1379(199805)19:3<235::AID-JOB837>3.0.CO;2-C

Argote, L., and McGrath, J.E. (1993). Group Process in Organizations: Continuity and Change, International 
Review of Industrial and Organizational Psychology, Vol. 8, pp. 333-389

Argyris, C., and Schön, D. (1978). Organizational learning: A theory of action perspective. MI: Addison-Wesley

Arnold, J.A., Arad, S., Rhoades, J.A., and Drasgow, F. (2000). The Empowering Leadership Questionnaire: The Construction and Validation of a New Scale for Measuring Leader Behaviors, Journal of Organizational Behavior, volume 21, pp. 249-269, http://dx.doi.org/10.1002/(SICI)1099-1379(200005)21:3<249::AID-JOB10>3.0.CO;2-\#

Avery, C.M. (2000). How Teamwork Can Be Developed As An Individual Skill, Journal for Quality \& Participation, Vol. 23 No. 4, pp. 6-13

Bain, A. (1998). Social Defenses against Organizational Learning, Journal of Human Relations, Volume 51 Number 3, pp. 413-429, http://dx.doi.org/10.1177/001872679805100309

Banker, R.D., Field, J.M., Schroeder, R.G. and Sinha, K.K. (1996). Impact of Work Teams on Manufacturing Performance: A Longitudinal Field Study, Academy of Management Journal, Vol. 39 No. 4, pp. 867-890

Barrick, M.B., Bradley, B.H., Kristof-Brown, A.L., and Colbert, A.E. (2007). The Moderating Role of Top Management Team Interdependence: Implications for Real Teams and Working Groups, Academy of Management Journal, Vol. 50, pp. 544-557, http://dx.doi.org/10.2307/256715

Beers, P.J. (2005). Negotiating Common Ground: Tools for Multidisciplinary Teams. PhD-thesis. Open University of the Netherlands: Heerlen. (Unpublished)

Bennett, Kremer, J, O'Brien, Michael, J. (1994). The Building Blocks of the Learning Organization, Training, Volume 31 Number 6, pp. 41-49

Berg, D. (1993). Expanding Perceptions, Possibilities and Profits, Journal for Quality and Participation, Vol. 16 No. 7, pp. 6-10

Boyett, J.H. and Conn, H.P. (1991). Workplace 2000: The Revolution Reshaping American Business. NY: Penguin

Brooks, A.K. (1994). Power and the Production of Knowledge: Collective Team Learning in Work Organizations, Human Resource Development Quarterly, Vol. 5 No. 3, pp. 213-35

Brwon, J.S. and Duguid, P. (1998).Organizing Knowledge, California Management Review, Vol. 40 No. 3, pp. 90-111

Buchanan, D. and Huczynski, A. (2004). Theory From Fiction: A Narrative Process Perspectives on Pedagogical Uses of Feature Film, Journal of Management Education, Vol. 28 No. 6, pp. 707-726, http://dx.doi.org/10.1177/1052562903262163

Chang, H. and Lee, A. (2001). The Relationship Between Psychological Safety, Organization Context Support and Team Learning Behavior in Taiwan, Global Journal of Engineering Education, Vol. 5, No. 2, pp. 185-192

Choo, C.W. Furness, C. Paquette, S. Van den Berg, H. Detlor, B. Bergeron, P. and Heaton, L. (2006). Working With Information: Information Management and Culture in a Professional Services Organization, Journal of Information Science, Vol. 32 No. 6, pp. 491-510, http://dx.doi.org/10.1177/0165551506068159

Christopher, C.A., Pearson, C.C. and Entrekin, L. (2003). Examining the Effects of Internal and External Team Learning on Team Performance, Team performance Management: An International Journal, Volume 9 Number 7/8, pp. 174-181

DeVellis, R.F. (1991). Scale Development: Theory and Applications. Newbury Park, CA: Sage Publications

Edmondson, A. (1999). Psychological Safety and Learning Behavior in Work Teams, Administrative Science Quarterly, Vol. 44, pp. 350-383, http://dx.doi.org/10.2307/2666999

Edmondson, A.C. (1996). Group and Organizational Influences on Team Learning. Unpublished Doctoral Dissertation, Harvard University, Boston, MA.

Edmondson, A.C., Dillon J.R., and Roloff K.S. (2007). Three Perspectives On Team Learning: Outcome Improvement, Task Mastery, and Group Process. In The Acad. Management Annals, edited by James P. Walsh and Arthur P. Brief, Psychology Press, pp. 269-314, http://dx.doi.org/10.1080/078559811

Entrekin, L. and Court, M. (2001). Human Resource Management: Adaptation and Change in an Age of Globalization. International Labor Office, Geneva.

Gibson, C., \& Vermeulen, F. (2003). A Healthy Divide: Subgroups as a Stimulus for Team Learning Behavior, Administrative Science Quarterly, Vol. 48, pp. 202-239, http://dx.doi.org/10.2307/3556657

Goodman, P. S., Ravlin, E., and Schminke, M. (1987). Understanding Groups in Organizations, Research in Organizational Behavior, Vol.9, pp. 121-173

Gryskiewicz, S.S. (1999). Positive Turbulence: Developing Climates for Creativity, Innovation, and Renewal. Jossey-Bass Publishers 
Hackman, J.R. (1983). A Normative Model of Work Team Effectiveness. (Technical Report No. 2). New Haven, CT: Yale School of Organization and Management.

Hackman, J.R. (1987). The Design of Work Teams. In J. Lorsch (Ed.), Handbook of Organizational Behavior. Englewood Cliffs, NJ: Prentice-Hall.

Hayes, J. and Allinson, C.W. (1998). Cognitive Style and the Theory and Practice of Individual and Collective Learning in Organizations, Human Relations, Vol. 51 No.7, pp. 847-871, http://dx.doi.org/10.1177/001872679805100701

Hill, R.B. and Petty, G. C. (1995). A New Look at Selected Employability Skills: A Factor Analysis of The Occupational Work Ethic, Journal of Vocational Education Research. Vol. 20 No. 4, pp. 59-73

Jassawalla, A.R. and Sashittal, H.C. (1999). Building Collaborative Cross-Functional New Product Teams, Academy of Management Executive, Vol. 13 No. 3, pp. 50-63, http://dx.doi.org/10.5465/AME.1999.2210314

Kasl E., Marsick V. and Dechant K. (1997). Teams as Learners: A Research-Based Model of Team Learning, Journal of Applied Behavioral Science, Vol. 33, pp. 227-246, http://dx.doi.org/10.1177/0021886397332010

Katzenbach, J.R. and Smith, D.K. (1993). The Rules For Managing Cross-Functional Reengineering Teams, Journal of Strategy and Leadership, Volume 21 No. 2, pp. 12-13

Kilgore, D. (2001). A Team Learning Intervention Into How Women Learn Empathy in Prison, Adult Education Quarterly, Vol. 51 No. 2, pp. 146-164, http://dx.doi.org/10.1177/07417130122087197

Kraut, A.I., Korman, A.K. (1999). Evolving Practices in Human Resource Management: Responses to a Changing World of Work. Jossey-Bass Publishers, San Francisco, CA

Loewen, P and Loo, R. (2004).Assessing Team Climate by Qualitative and Quantitative Approaches Building The Learning Organization, The Learning Organization, Vol. 11 No. 3, pp. 260-272

Lundberg, C.C. (1995). Learning in and by Organizations: Three Conceptual Issues, International Journal of Organizational Analysis, Vol. 3 No. 1, pp. 353-360

Luthans, F. (1995). Organizational Behavior. McGraw-Hill Education

Mathieu, J., Rapp, T. and Gilson, L. (2008).Team Effectiveness 1997-2007: A Review of Recent Advancements and a Glimpse into the Future, Journal of Management, Vol. 34 No. 3, pp. 410-476, http://dx.doi.org/10.1177/0149206308316061

Savelsbergh. C., Heijden. B. and Poell. R. (2007). Explaining Differences in Team Performance Does team learning behavior matter? INGRoup Conference http://www.kennisenco.nl/publicaties/Savelsbergh\%20C\%20Heijden\%20vd\%20B\%20Poell\%20R\%20FINAL\%20VE RSION.pdf

Schippers, M. C., Den Hartog, D. N., Koopman, P. L, \& Wienk, J. A. (2003). Diversity and Team Outcomes: The Moderating Effects of Outcome Interdependence and Group Longevity and The Mediating Effect of Reflexivity, Journal of Organizational Behavior, Vol. 24 No. 6, pp. 779-802, http://dx.doi.org/10.1002/job.220

Senge, P.M. (1992). The Fifth Discipline: The Art \& Practice of the Learning Organization. Random House Australia, Milson Point, New South Wales

Senge, P.M., Roberts, C., Ross, R.B., Smith, B.J. and Kleiner, A. (1994). The Fifth Discipline Fieldbook: Strategies and Tools for Building a Learning Organization. Doubleday, New York, NY

Shivastrava, A. Bartol. K., \& Locke E. (2006). Empowering Leadership in Management Teams: Effects on Knowledge Sharing, Efficacy, and Performance, Academy of Management Journal, Vol. 49 No. 6, pp. 1239-1251

Stewart, G. L. (2006). A Meta-Analytic Review of Relationships Between Team Design Features and Team Performance, Journal of Management, Vol. 32, pp. 29-54, http://dx.doi.org/10.1177/0149206305277792

Sundstrom, E. (1999). Supporting Work Team Effectiveness: Best Management Practices for Fostering High Performance. Jossey-Bass.

Tinsley, H. E. A. \& Tinsley, D. J. (1987). Uses of Factor Analysis in Counseling Psychology Research, Journal of Counseling Psychology, Vol. 34 No. 4, pp. 414-424, http://dx.doi.org/10.1037//0022-0167.34.4.414

Van den Bossche, P., Gijselaers W., Segers M. \& Kirschner P.A. (2006). Social and Cognitive Factors Driving Teamwork in Collaborative Learning Environments: Team Learning Beliefs and Behaviors, Small Group Research, Vol. 37, pp. 490-521, http://dx.doi.org/10.1177/1046496406292938

Van der Vegt, G. (1998). Patterns of Interdependence in Work Teams: A Cross-Level Examination of The Relation With Satisfaction and Commitment. Rijksuniversiteit Groningen, Groningen, http://dx.doi.org/10.1177/1059601198232003 
Van der Vegt, G., \& Bunderson, S. (2005). Learning and Performance in Multidisciplinary Teams: The Importance of Collective Team Identification, Academy of Management Journal, Vol. 48 No. 3, pp. 532-547, http://dx.doi.org/10.5465/AMJ.2005.17407918

Van Dyck, C., Frese, M., Baer, M. and Sonnentag, S. (2005). Organizational Error Management Culture And Its Impact on Performance: A Two-Study Replication, Journal of Applied Psychology, Vol. 90 No. 6, pp. 1228-1240, http://dx.doi.org/10.1037/0021-9010.90.6.1228

Van Woerkom, M. (2003). Critical Reflection at Work: Bridging Individual and Organizational Learning. Ph.D. dissertation, University of Twente, Netherlands.

Wellins, R.S., Byham, W.C. and Wilson, J.M. (1991). Empowered Teams: Creating Self-Directed Work Groups that improve Quality, Productivity, and Participation. Jossey-Bass Publishers, San Francisco, CA.

Zellmer-Bruhn, M. and Gibson C. (2006). Multinational Organization Context: Implications for Team Learning and Performance, Academy of Management Journal, Vol. 49 No. 3, pp. 501-518, doi:10.5465/AMJ.2006.21794668, http://dx.doi.org/10.5465/AMJ.2006.21794668

Table 1. Internal Learning, External Learning and Team Performance Factor Analysis

\begin{tabular}{|c|c|c|c|}
\hline Factors and items & 1 & 2 & 3 \\
\hline \multicolumn{4}{|l|}{ Internal Learning $(\alpha=0.736)$} \\
\hline $\begin{array}{l}\text { 1. Problems and errors in our group are never communicated to the appropriate people so that corrective action can } \\
\text { be taken. (reverse coded) }\end{array}$ & 0.854 & & \\
\hline 2. People in my group often speak up to test assumptions about issues under discussion. & 0.829 & & \\
\hline 3. In our group, people discuss ways to prevent and learn from mistakes & 0.788 & & \\
\hline 4. In my group, someone always sure that we stop to reflect on our work process & 0.374 & & \\
\hline 5. We regularly take time to figure out ways to improve our work processes. & 0.284 & & \\
\hline \multicolumn{4}{|l|}{ External Learning $\quad(\alpha=0.636)$} \\
\hline $\begin{array}{l}\text { 1. Group members go out and get all the relevant work information they possibly can from others -such as } \\
\text { customers, or other parts of the organization. }\end{array}$ & & & 0.670 \\
\hline 2. My group keeps others in the organization informed about what we plan and accomplish. & & & 0.666 \\
\hline 3. We invite people from outside the group to present information or have discussions with us. & & & 0.628 \\
\hline 4. My group frequently coordinates with other groups to meet organizational objectives. & & & 0.563 \\
\hline $\begin{array}{l}\text { 5. We don't have time to communicate information about our group's work to others who are not in the group. } \\
\text { (reverse coded) }\end{array}$ & & & 0.472 \\
\hline \multicolumn{4}{|l|}{ Team performance $\quad(\alpha=0.707)$} \\
\hline 1. Others in the company who interact with my group often complain about how we function. (reverse coded) & & 0.765 & \\
\hline 2. Others often complain about my group's work. (reverse coded) & & 0.716 & \\
\hline 3. Quality errors occur frequently in my group.(reverse coded) & & 0.657 & \\
\hline $\begin{array}{l}\text { 4. Recently, my group seems to be "slipping" a bit in its level of performance and accomplishments. } \\
\text { coded) }\end{array}$ & & 0.502 & \\
\hline 5. The quality of work provided by my group is improving. & & 0.389 & \\
\hline Eigenvalues & 4.385 & 1.992 & 1.588 \\
\hline Cumulative percentage of variance & 29.236 & 42.518 & 53.108 \\
\hline
\end{tabular}


Table 2. Descriptive statistics Internal Learning, External Learning and Team Performance

\begin{tabular}{|c|c|c|c|}
\hline Items & $\mathrm{N}$ & Mean & S.D. \\
\hline \multicolumn{4}{|l|}{ Internal Learning } \\
\hline $\begin{array}{l}\text { 1. Problems and errors in our group are never communicated to the appropriate people so that corrective action can be } \\
\text { taken. }\end{array}$ & 49 & 5.39 & 1.605 \\
\hline 2. People in my group often speak up to test assumptions about issues under discussion. & 49 & 5.35 & 1.316 \\
\hline 3. In our group, people discuss ways to prevent and learn from mistakes & 49 & 5.78 & 1.104 \\
\hline 4. In my group, someone always sure that we stop to reflect on our work process & 49 & 5.22 & 1.624 \\
\hline 5. We regularly take time to figure out ways to improve our work processes. & 49 & 6.02 & 0.989 \\
\hline \multicolumn{4}{|l|}{ External Learning } \\
\hline $\begin{array}{l}\text { 1. Group members go out and get all the relevant work information they possibly can from others -such as customers, or } \\
\text { other parts of the organization. }\end{array}$ & 49 & 5.78 & 1.159 \\
\hline 2. My group keeps others in the organization informed about what we plan and accomplish. & 49 & 5.49 & 1.293 \\
\hline 3. We invite people from outside the group to present information or have discussions with us. & 49 & 4.76 & 1.588 \\
\hline 4. My group frequently coordinates with other groups to meet organizational objectives. & 49 & 5.43 & 1.118 \\
\hline 5. We don't have time to communicate information about our group's work to others who are not in the group. & 49 & 4.37 & 1.867 \\
\hline \multicolumn{4}{|l|}{ Team performance } \\
\hline 1. Others in the company who interact with my group often complain about how we function. & 49 & 5.80 & 1.291 \\
\hline 2. Others often complain about my group's work. & 49 & 5.69 & 1.503 \\
\hline 3. Quality errors occur frequently in my group. & 49 & 5.80 & 1.369 \\
\hline 4. Recently, my group seems to be "slipping" a bit in its level of performance and accomplishments. & 49 & 5.16 & 1.612 \\
\hline 5. The quality of work provided by my group is improving. & 49 & 5.94 & 0.899 \\
\hline
\end{tabular}

Table 3. Correlations between Team performance, Internal Team Learning, and External Team Learning

\begin{tabular}{|lccc|}
\hline & Team Performance & Internal Team Learning & External Team Learning \\
\hline Team Performance & 1 & $0.400^{* *}$ & $0.379^{* *}$ \\
Internal Team Learning & $0.400^{* *}$ & 1 & $0.377^{* *}$ \\
External Team learning & $0.379^{* *}$ & $0.377^{* *}$ & 1 \\
\hline
\end{tabular}

**. Correlation is significant at the 0.01 level (2-tailed).

Table 4. Team performance model 1

\begin{tabular}{|ccccccc|}
\hline Dependent variable & Independent variables & Std $\beta$ & Significance & Model Adj. $R 2$ & $F$ & Significance \\
\hline Team performance & Internal Team Learning & 0.400 & 0.004 & 0.142 & 8.944 & 0.004 \\
\hline
\end{tabular}

Table 5. Team performance regression model 2

\begin{tabular}{|ccccccc|}
\hline Dependent variable & Independent variables & $S t d \beta$ & Significance & Model Adj. $R 2$ & $F$ & Significance \\
\hline Team performance & External Team Learning & 0.379 & 0.007 & 0.125 & 7.861 & 0.007 \\
\hline
\end{tabular}

Table 6. Team Performance regression model 3

\begin{tabular}{|lcccccc|}
\hline Dependent variable & Independent variables & $S t d \beta$ & Significance & Model Adj. $R 2$ & $F$ & Significance \\
\hline \multirow{2}{*}{ Team performance } & Internal Team Learning & 0.300 & 0.038 & 0.187 & 6.502 & 0.003 \\
& External Team Learning & 0.266 & 0.065 & & & \\
\hline
\end{tabular}

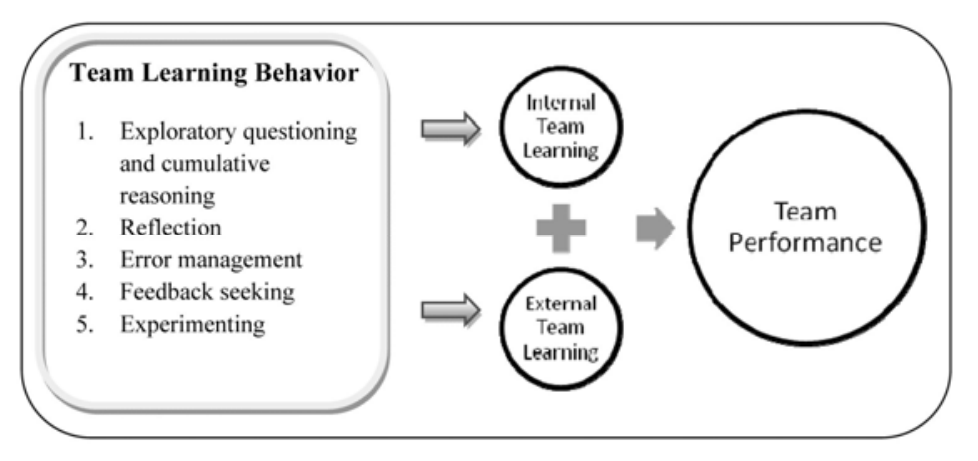

Figure 1. Conceptual model 